\title{
Root System Architecture and Nitrogen Uptake Efficiency of Wheat Species
}

\author{
K.M.C. Fernando ${ }^{1 *}, 2$, O.G. Ehoche ${ }^{1}$, J.A. Atkinson ${ }^{1}$ and D.L. Sparkes ${ }^{1}$
}

Date Received: $16^{\text {th }}$ July 2020 / Date Accepted: $2^{\text {nd }}$ September 2020

\begin{abstract}
Purpose: Plant nitrogen use efficiency can be increased by improving $N$ uptake efficiency (NUpE). Root system architecture of the plant plays a vital role in uptaking water and nutrients including $N$. The present study was conducted to compare root architectural traits of different wheat species at early seedling development and vegetative growth stage while plant nitrogen uptake at vegetative and mature stages under controlled environment.

Research Method: Ten genotypes belong to four wheat species; einkorn, emmer, spelt and modern bread wheat were compared. Growth pouches were used to develop root systems of seedlings and images were analysed by using RootNav software. Root charcteristics and above-graound growth at vegetative growth phase was studied using semihydrophonic system where WinRhizo software was used to analyse root images. Finally, glasshouse pot experiment was conducted to calculate $N U p E$ at maturity.
\end{abstract}

Findings : The highest number of seminal roots, total root length and wider tip angle of seminal root were recorded in emmer. However, total root length was not significantly different from spelt cv. Oberkulmer. Genotypes with narrow and wide tip angles of seminal roots produced deep and shallow seedling root systems, respectively. Positive relationship between root traits and nitrogen uptake at the vegetative growth stage was found. Fertiliser NUpE of ancient wheat species varied significantly among genotypes where emmer recorded the highest value followed by spelt, bread wheat and einkorn.

Originality/Value : Wheat species varied for seedling root system architecture. Emmer had wide and shallow seedling root systems while having high NUpE at maturity. It suggests the importance of a wellspred shallow root system to uptake $N$ fertiliser rapidly before leached down. Further, emmer is an ancient wheat species with an ability to uptake $N$ efficiently which suggests that when bread wheat was selected for high yield, favourable root traits related to $N U p E$ might be neglected. Favourable root traits in emmer related to $N U p E$ could be introduced to bread wheat through the direct crossing or creating synthetic wheat.

Keywords: nitrogen uptake efficiency, nitrogen use efficiency, root architecture, wheat

\section{INTRODUCTION}

Nitrogen $(\mathrm{N})$ is an essential element for crop growth and development (Kraiser et al., 2011). Globally, the application of $\mathrm{N}$ fertiliser in agriculture has increased significantly during the last five decades (Hirel et al., 2007), with half of the global food production dependent on synthetic $\mathrm{N}$ fertiliser (Dawson and Hilton, 2011). The average application of $\mathrm{N}$ fertiliser to winter wheat in the UK was $220 \mathrm{~kg} \mathrm{~N} \mathrm{ha}^{-1}$ in 2011 (Defra, 2012) but only some portion of this is taken up by the crop (Barraclough et al., 2010). The unused
$\mathrm{N}$ fertiliser in agriculture has many potential detrimental effects on the environment. It may be lost as surface runoff, leached as nitrate $\mathrm{NO}_{3}^{-}$ ), and through volatilisation and production of

\footnotetext{
Division of Agriculture and Environmental Sciences, University of Nottingham, Sutton Bonnington Campus, Loughborough, Leicestershire, LE12 5RD, The United Kingdom menaka@crop.ruh.ac.lk

2 Department of Crop Science, Faculty of Agriculture, University of Ruhuna, Mapalana, Kamburupitiya 81100, Sri Lanka

D http://orcid.org/0000-0002-6130-7669
} 
nitrous oxide gas due to microbial denitrification (Conley et al., 2009). Improving $\mathrm{N}$ use efficiency (NUE; grain yield per unit $\mathrm{N}$ availability) of cereal crops through $\mathrm{N}$ management strategies (Liao et al., 2006), traditional plant breeding methods and biotechnology, while maintaining sustainable yield, would be beneficial to farmers and the environment (Beatty et al., 2010). NUE can be achieved by improving $\mathrm{N}$ uptake efficiency (NUpE; plant $\mathrm{N}$ uptake per unit $\mathrm{N}$ availability in the soil) and/or N utilisation efficiency (NUtE; grain yield per unit plant $\mathrm{N}$ uptake) (Garnett et al., 2009; Ehdaie et al., 2010).

Based on the results of QTL studies for $\mathrm{N}$ uptake and root traits, it has been suggested that breeding crops with efficient root systems to maximise $\mathrm{N}$ uptake is an important goal in wheat breeding (Atkinson et al., 2015). Selection for root architectural traits in crop breeding programmes depends on understanding the various components of root architecture (Lynch and Brown, 2012). Bowman et al. (1998), experimenting on bentgrass, concluded that plants with large and deep root systems utilise more $\mathrm{N}$ fertiliser than those with small and shallow root systems. Deep and narrow root systems provide opportunities to uptake more $\mathrm{N}$ from deeper layers of the soil (Garnett et al., 2009). Rooting depth of wheat and barley, like other crops, depends on soil texture, structure, nutrition and depth of the groundwater table (Barraclough et al., 1991). Furthermore, plants with higher root surface area due to lateral branches and root hairs have the ability to take up more $\mathrm{N}$ than plants with sparse root systems (Liao et al., 2004; Gahoonia et al., 2007). To acquire sufficient $\mathrm{N}$, plants increase root length density to explore a greater soil volume and increase $\mathrm{N}$ uptake (Liu et al., 2009) while deep rooting enables plants to takeup residual $\mathrm{N}$ from the subsoil (Barraclough et al.,2010). Root length and root biomass of wheat have shown to possess strong correlation with $\mathrm{N}$ uptake suggesting the contribution of those two traits towards the efficiency of $\mathrm{N}$ uptake (Brady et al., 1993; Bowman et al., 2002).

Nakomoto and Oyangi (1994), working with Japanese wheat germplasm, found that genotypes with narrower angles of seminal roots ended up with deep root systems while shallow root systems had the much wider angle and horizontally grown seminal roots. Similarly, Manschadi et al. (2008), based on the results of 27 Australian and three CIMMYT wheat genotypes, suggested that seedling seminal root angle is a major influence on mature root architecture. Genotypes with narrow seminal root angles at seedling stage developed deep and compact root systems at maturity, when compared to shallow seminal root angled seedlings.

Breeding for efficient use of $\mathrm{N}$ in crop plants requires adequate genetic variability for selection of useful traits. However, genetic diversity of modern bread wheat is narrowed due to random hybridisation events and selective breeding for high yield. Hence, it has become necessary to search for novel sources of genetic variation for $\mathrm{NUpE}$. One of the sources could be the ancient wheat species; einkorn, emmer and splet (Trethowan and Mujeeb-Kazi, 2008; Sparkes, 2010). The aims of this study were to investigate the variability of seedling root system architecture and nitrogen uaptake at maturity of different wheat species.

\section{MATERIALS AND METHODS}

Three ancient hulled wheat species (einkorn, emmer, spelt) and bread wheat were used as genetic materials for experiments conducted in 2013, under controlled environment conditions at Sutton Bonington Campus, University of Nottingham, UK. Three einkorn (Triticum monococcum L.) genotypes (einkorn 1, einkorn 2 and einkorn 3), two genotypes of emmer ( $T$. dicoccum) (emmer 1 and emmer 2 ), three cultivars (cvs) of spelt (T. spelta L.) (SB, Oberkulmer and Tauro) and two cvs of modern bread wheat (Xi 19 and JB Diego) were compared. Uniform seeds of the same diameter were selected using a set of sieves. The seed size of bread wheat cvs, spelt cvs, emmer 1, emmer 2 and einkorn 2 ranged from 2.8 to $3.35 \mathrm{~mm}$ while einkorn 1 and einkorn 3 were between 2 to $2.8 \mathrm{~mm}$. 


\section{Experiment 1: $2 D$ root phenotyping in growth pouches}

The experiment was set up as a completely randomised design with 27 replicates. There were 27 plastic containers with ten place holders and each place had a unique number. Each place holder contains one genotype. Seeds were surface sterilised by submerging in $70 \%(\mathrm{v} / \mathrm{v})$ ethanol for 60 seconds and then in $5 \%(\mathrm{v} / \mathrm{v})$ sodium hypochlorite $(\mathrm{NaOCl})$ solution for 10 minutes. Seeds were then rinsed thoroughly with sterilised distilled water and germinated on moist blotting paper under dark conditions at $4^{\circ} \mathrm{C}$.

Growth pouches consisting of black polythene sheet and blue germination blotting paper were used. The black polythene and blue blotting paper $(24.1 \times 30 \mathrm{~cm}$, Anchor Paper, St. Paul, MN, USA) were attached to a plastic rod with two $19 \mathrm{~mm}$ foldback clips, one on each side of the upper edge of the pouch (Xie et al., 2017). Two days after germination, seeds were placed on the moistened blotting paper with the embryo facing downwards in the growth pouches. Then growth pouches were hung into the plastic containers with $2 \mathrm{~cm}$ of the lower end immersed in the nutrient solution (1/4 strength of Hoagland's No. 2, Basal Salt Mixture, Sigma). The composition of the basal salt mixture was $\mathrm{KNO}_{3}(606.6 \mathrm{mg}$ $\left.1^{-1}\right), \mathrm{Ca}\left(\mathrm{NO}_{3}\right)_{2}\left(656.4 \mathrm{mg} \mathrm{l}^{-1}\right), \mathrm{MgSO}_{4}(240.76$ $\left.\mathrm{mg} \mathrm{l}^{-1}\right), \mathrm{NH}_{4} \mathrm{H}_{2} \mathrm{PO}_{4}\left(115.03 \mathrm{mg} \mathrm{l}^{-1}\right), \mathrm{MnCl}_{2} .4 \mathrm{H}_{2} \mathrm{O}$ $\left(1.81 \mathrm{mg} \mathrm{l}^{-1}\right), \mathrm{H}_{3} \mathrm{BO}_{3}\left(2.86 \mathrm{mg} \mathrm{l}^{-1}\right), \mathrm{MoO}_{3}(0.016$ $\left.\mathrm{mg} \mathrm{l}^{-1}\right), \mathrm{ZnSO}_{4} .7 \mathrm{H}_{2} \mathrm{O}\left(0.22 \mathrm{mg} \mathrm{l}^{-1}\right), \mathrm{CuSO}_{4} .5 \mathrm{H}_{2} \mathrm{O}$ $\left(0.08 \mathrm{mg} \mathrm{l}^{-1}\right)$ and $\mathrm{Fe}_{2}\left(\mathrm{C}_{4} \mathrm{H}_{4} \mathrm{O}_{6}\right)_{3}\left(5 \mathrm{mg} \mathrm{l}^{-1}\right)$.

The pouches were kept in the growth room under a 12 hour light/dark cycle at $18^{\circ} \mathrm{C}$ during light and $13^{\circ} \mathrm{C}$ during dark photoperiod and a photon flux density of $400 \mu \mathrm{mol} \mathrm{m} \mathrm{m}^{-2} \mathrm{~s}^{-1}$ for two weeks before capturing images. Images of root systems were obtained using a digital SLR camera (Nikon D5100 DSLR) mounted on a modified copy stand. The images were analysed using RootNav software to quantify the number of seminal and lateral roots, total root length, seminal and lateral root length, maximum width, maximum depth convex hull (the area covered by all root materials), tip angles of seminal roots and emergence angles of seminal roots (Pound et al., 2013).

\section{Experiment 2: Root morphology at vegetative stage in semi-hydrophonic system}

The second experiment was set up according to randomised complete block design with three replicates to account for the variation of photosynthetically active radiation $\left(\mu \mathrm{mol} \mathrm{m} \mathrm{m}^{-2} \mathrm{~s}^{-1}\right)$ in the glasshouse. The seeds were sown in sand compost medium (Levington $\mathrm{F} 2+\mathrm{S}$ ) consisting $\mathrm{N} 150 \mathrm{~g} \mathrm{~m}^{-3}$, P $200 \mathrm{~g} \mathrm{~m}^{-3}$, K $350 \mathrm{~g} \mathrm{~m}^{-3}$ and $\mathrm{pH}$ 5.3-5.7. Ten day old healthy seedlings were transplanted into 3 litre pots filled with hydroleca clay pellets. Plants were treated with a complete nutrient solution (Standard HortiMix $1.0 \mathrm{~g} \mathrm{l}^{-1}$ ) twice daily for the first two weeks and once daily for the remaining period of the experiment. The composition of the HortiMix was $\mathrm{NO}_{3}^{-}(850 \mathrm{mg}$ $\left.\mathrm{l}^{-1}\right), \mathrm{NH}_{4}^{-}\left(140 \mathrm{mg} \mathrm{l}^{-1}\right),\left(\mathrm{NH}_{2}\right)_{2} \mathrm{CO}\left(510 \mathrm{mg} \mathrm{l}^{-1}\right)$, $\mathrm{P}_{2} \mathrm{O}_{5}\left(700 \mathrm{mg} \mathrm{l}^{-1}\right), \mathrm{K}_{2} \mathrm{O}\left(300 \mathrm{mg} \mathrm{l}^{-1}\right), \mathrm{MgO}(160$ $\left.\mathrm{mg} \mathrm{l}^{-1}\right)$, Fe EDTA (15.3 $\left.\mathrm{mg} \mathrm{l}^{-1}\right)$, Mn (10 $\left.\mathrm{mg} \mathrm{l}^{1^{-1}}\right)$, $\mathrm{B}\left(3 \mathrm{mg} \mathrm{l}^{-1}\right), \mathrm{Zn}\left(2.7 \mathrm{mg} \mathrm{l}^{-1}\right), \mathrm{Cu}\left(2 \mathrm{mg} \mathrm{l}^{-1}\right)$ and Mo (1.2 $\left.\mathrm{mg} \mathrm{l}^{-1}\right)$. Adequate water was supplied throughout the experiment. The experiment was conducted under natural daylight and the maximum temperature of $30^{\circ} \mathrm{C}$.

Plants were harvested at nine day intervals at 14, 23, 32 and 41 days after transplanting (DAT). At each sampling date, a leaf area meter (LI-3100 Area Meter, LI-COR inc, Lincoln, Nebraska, USA) was used to measure the green area of the plant $\left(\mathrm{cm}^{2}\right)$ before being dried at $80^{\circ} \mathrm{C}$ for 48 hours to establish biomass. Soil Plant Analysis Development (SPAD meter) (Minolta, Osaka, Japan) was used to measure chlorophyll concentration index, an indicator of chlorophyll content of the green leaves, avoiding leaf midrib due to thickness and paleness which could affect readings. SPAD measurements were taken on the fully developed, newest emerged leaf.

Roots were extracted from the hydroleca and thoroughly washed with tap water. Cleaned root samples were digitised at 400 dpi resolution and 256 grey contrasts (tiff format) with a scanner with a transparency adapter (WinRHIZO STD 1600+, Regent Instruments Inc., Quebec; Canada). The scanned images of the root systems were analysed using WinRHIZO regular V.2002c software (WinRHIZO STD 1600 +, Regent Instruments Inc., Quebec; Canada). Total 
root length, mean diameter, root volume and root length in different diameter classes were measured. Following scanning, roots were ovendried at $80^{\circ} \mathrm{C}$ for 48 hours before determining their dry weight. Specific root length (length to mass ratio), root length density (length to volume ratio), root elongation rate (root length difference at two sampling points divided by the number of days between sampling points) and root $\mathrm{N}$ uptake efficiency $\left(\mathrm{NUpE}_{\mathrm{R}}\right.$; plant $\mathrm{N}$ content to unit root biomass or root length) were calculated. The specific absorption rate of $\mathrm{N}\left(\mathrm{S}_{\mathrm{AB}} \mathrm{R}_{\mathrm{N}}\right)$ was calculated based on the relationship described by Hackett (1969) and Liao et al. (2004). It was calculated based on root biomass and total root length for the period between the first sampling (14 DAT) and the last sampling (41 DAT), using Equation 1.

$\mathrm{S}_{\mathrm{AB}} \mathrm{R}_{\mathrm{N}}=\left(\mathrm{PN}_{2}-\mathrm{PN}_{1} / \mathrm{T}_{2}-\mathrm{T}_{1}\right) \times\left(\ln \mathrm{R}_{2}-\ln \mathrm{R}_{1} / \mathrm{R}_{2}-\mathrm{R}_{1}\right)$

Equation (1)

Where, $\mathrm{PN}=$ total plant $\mathrm{N}(\mathrm{mg}), \mathrm{T}=$ time in days, $\mathrm{R}=$ root biomass $(\mathrm{mg})$ or total root length $(\mathrm{m})$.

Finely ground plant material (particle size of $<$ $200 \mu \mathrm{m}$. 45 to $50 \mathrm{mg}$ ) was used to analyse N\%. Dumas method was applied by using a Fisons NA-2000 elemental analyser (Fisons, Ipswich, UK) calibrated against Methyl-N standard (N content $=9.28 \%$ ). $\mathrm{N}$ uptake of the plant (except roots) was calculated using Equation 2.

Plant $\mathrm{N}$ uptake $(\mathrm{g} \mathrm{N})=$ Plant dry weight $(\mathrm{g}) \times \mathrm{N}$ content of the plant (\%)

Equation (2)
$\mathrm{F} 2+\mathrm{S}$ ) and kept in a growth room at $4^{\circ} \mathrm{C}$ for eight weeks to fulfil their vernalisation requirement. Eight weeks after germination, selected healthy plants were transplanted into two litre black plastic pots with one plant per pot, containing low $\mathrm{N}$ compost with $\mathrm{P} 125 \mathrm{gm}^{-3}$ and $\mathrm{K} 300 \mathrm{gm}^{-3}$. The experiment was set up as split-plot design where $\mathrm{N}$ treatment was randomised on the main plots, genotypes were randomised on the subplots and each treatment was replicated three times. Two levels of $\mathrm{N}$ fertiliser were imposed at an equivalent rate of $50 \mathrm{kgN} \mathrm{ha}^{-1}(\mathrm{LN})$ and 200 $\mathrm{kgN} \mathrm{ha}^{-1}(\mathrm{HN})$. Ammonium nitrate was applied in liquid form and $50 \mathrm{kgN} \mathrm{ha}^{-1}$ was applied 3 days after transplanting for all plants. Two more applications of $50 \mathrm{kgN} \mathrm{ha}^{-1}$ and100 $\mathrm{kgN} \mathrm{ha}^{-1}$ were used for $\mathrm{HN}$ treatment at stem elongation and flag leaf emergence. The experiment was conducted under natural daylight and the maximum temperature of $30^{\circ} \mathrm{C}$. Destructive sampling was done at maturity and grain yield and above ground biomass were recorded. Total plant nitrogen uptake (except $\mathrm{N}$ in roots) was calculated based on $\mathrm{N}$ content of the plant. $\mathrm{N}$ $\%$ of the straw, chaff and grain were analysed according to Dumas method. $\mathrm{N}$ uptake efficiency of the plant was calculated using Equation 3.

$\mathrm{NUpE}=[$ Total plant $\mathrm{N}$ uptake $(\mathrm{g}) /$ total $\mathrm{N}$ availability (fertiliser) (g)] x 100

Equation (3)

\section{Statistical analysis}

Data were analysed using GenStat $15^{\text {th }}$ edition. ANOVA appropriate to the design of each experiment was performed. Mean differences were tested using LSD at 5\% probability level. Pearson correlation analysis was used to examine the relationships between different root architectural traits and above ground growth parameters.

\section{Experiment 3: Glasshouse pot experiment}

One seed, per hole, was sown in modular trays filled with sand compost media (Levington 


\section{RESULTS}

Three experiments were conducted to study seedling root systems architecture on growth pouches, root morphology and $\mathrm{N}$ uptake at vegetative stage and $\mathrm{NUpE}$ at maturity for ten genotypes of four wheat species. Seedling root architectural traits were measured using images under undisturbed conditions in experiment 1 . The mean number of seminal and lateral roots were significantly different between genotypes at 14 days after transferral (DAT) to growth pouch.
The greatest number of seminal roots $(5.25, P<$ $0.001)$ and lateral roots $(1.42, P<0.01)$ were recorded in emmer 2, while the lowest number of seminal roots (3.72) was recorded in bread wheat cultivar (cv.) JB Diego (Figure 01A). Einkorn 1 and einkorn 2 did not produce any lateral roots within 14 days. Spelt cv. Oberkulmer produced the longest seminal root $(141.6 \mathrm{~mm}, P<0.001)$ (Figure 01B). However, all spelt genotypes, emmer 1, bread wheat cv. JB Diego also had long seminal roots at 14 DAT.
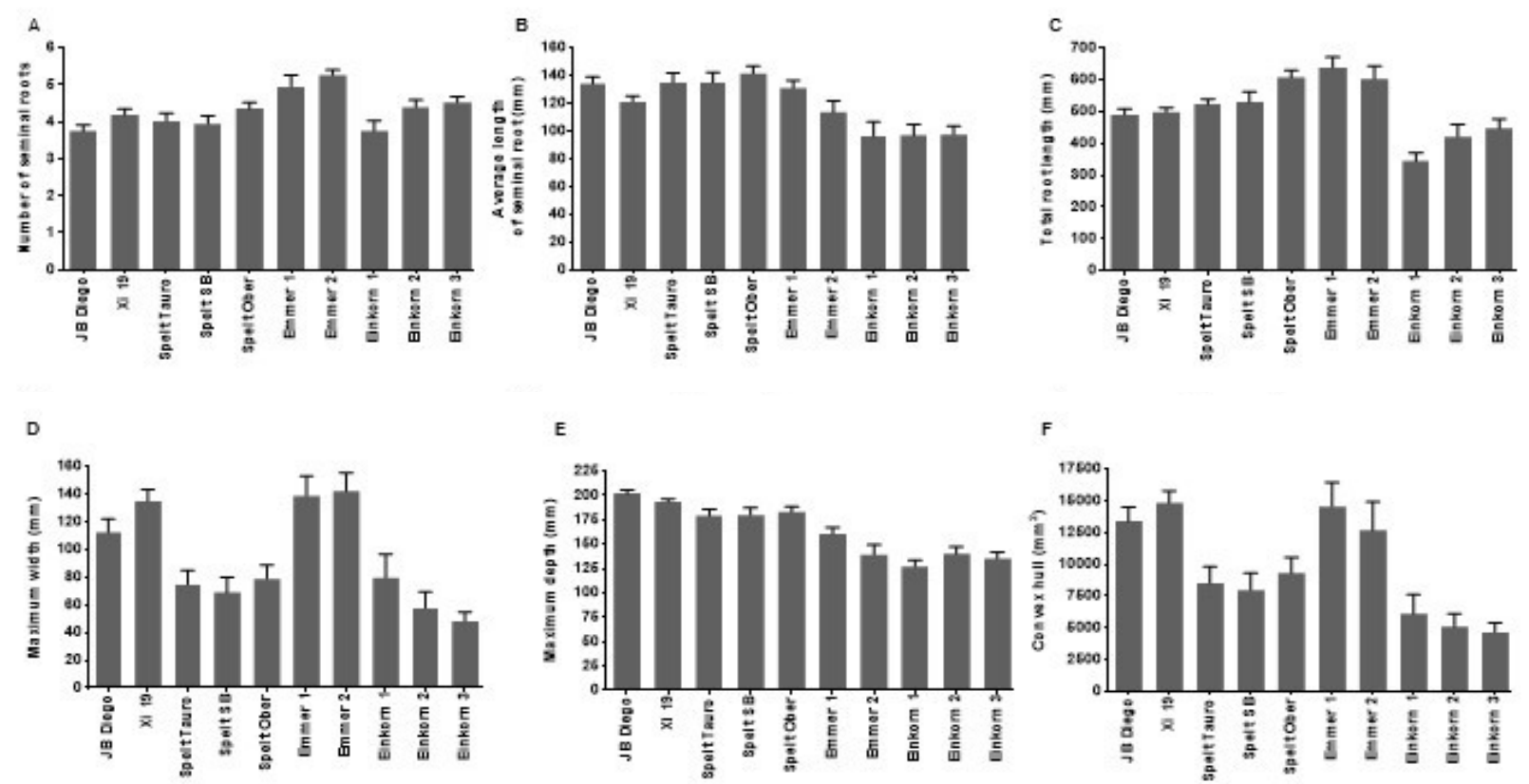

H
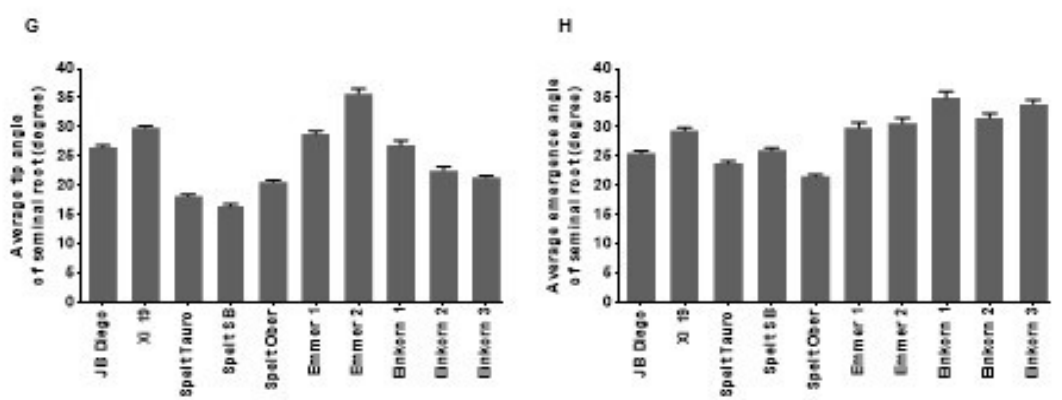

Figure 01: Phenotypic variation of root system architectural traits. (A) Number of seminal roots (B) average length of a seminal root $(\mathrm{mm})(\mathrm{C})$ total root length $(\mathrm{mm})(\mathrm{D})$ maximum width $(\mathrm{E})$ maximum depth $(\mathrm{F})$ convex hull $\left(\mathrm{mm}^{2}\right)(\mathrm{G})$ average tip angle of seminal root (degree) $(\mathrm{H})$ average emergence angle of seminal root (degree), of the root systems grown vertically on growth pouches at 14 DAT. Error bars represent SE of the means of genotypes. 
Total root length was significantly longer in emmer 1 (614.20 mm, $P<0.001)$ when compared to all other genotypes (Figure 01C). The average length of lateral roots was not significantly different between genotypes. Emmer 2 produced root systems with maximum width of 143.74 $\mathrm{mm}(P<0.001)$ (Figure 01D) and width to depth ratio $(1.06, P<0.001)$. Root systems of einkorn genotypes were narrow and shallower than all other genotypes. It was observed that bread wheat cv. JB Diego had a deep root system (Figure 01E) recording the maximum root depth of 201.56 $\mathrm{mm}(P<0.001)$. Average width to depth ratio for emmer, bread wheat, einkorn and spelt was 0.97 , $0.63,0.48$ and 0.42 , respectively. The convex hull of the root system was significantly different between genotypes; highest in Xi 19 and lowest in einkorn 3 (Figure 01F). Tip angle of the seminal roots was significantly different among genotypes in the range of $16.73^{\circ}$ to $35.78^{\circ}$ (Figure $01 \mathrm{G})$. Emmer 2 recorded the widest tip angle of seminal roots while narrow angles of seminal roots were observed in all spelt genotypes. Average emergence angle of the seminal root was $21.6^{\circ}$ to $35.1^{\circ}$ between genotypes $(P<$ 0.01 ) (Figure $01 \mathrm{H}$ ). Einkorn 1 showed the widest emergence angles at 14 DAT while spelt Oberkulmer had the narrowest emergence angle which was $61 \%$ narrower than einkorn 1. Nevertheless, the average emergence angle of einkorn was not significantly different from emmer species. Also, the emergence angle of emmer was not significantly different from bread wheat while spelt had the narrowest emergence angle at 14 DAT. Figure 02 and 3 show root system architecture (RSA) of 10 genotypes at 14 DAT.
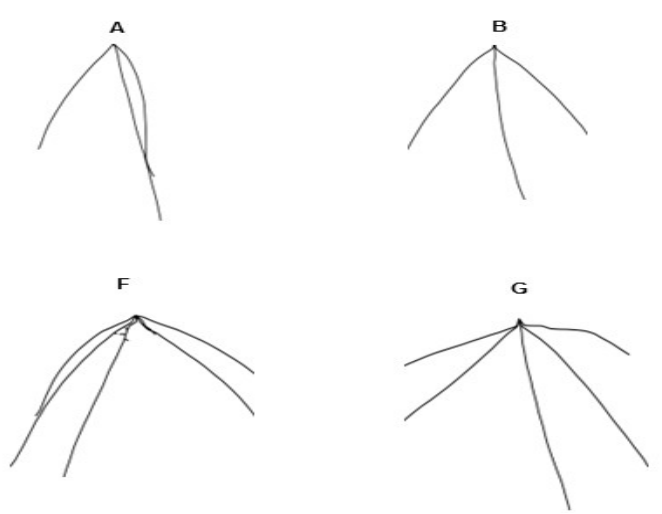

There was a positive correlation between the tip angle of the seminal roots and the maximum width of the root system $(\mathrm{r}=0.84 ; P<0.001)$. Also, the ratio between width to depth was strongly correlated with the tip angle of the seminal roots $(\mathrm{r}=0.92, P<0.001)$. A strong relationship was observed between the average length of seminal root and the maximum depth of the root system $(\mathrm{r}=0.85 ; P<0.01)$.

At every sampling date, genotypes differed in the number of tillers per plant $(P<0.001)$ in Experiment 2. Spelt SB had the most tillers while einkorn 2 produced the least. When averaged across species, emmer and spelt showed vigorous tiller production at 41 DAT (Table 01). Green area was the highest in spelt at most of the sampling points followed by emmer, then bread wheat and least in einkorn $(P<0.001)$ (Table 01). Spelt and emmer produced the most shoot biomass when compared to bread wheat and einkorn $(P<0.001)$ (Table 02).

Chlorophyll concentration index of the leaf (as SPAD value) was very high in bread wheat cv. Xi 19 throughout the experiment, despite the fact that all genotypes were supplied with the same amount of nutrients (data not shown). The spelt and emmer genotypes had low SPAD values representing less $\mathrm{N}$ in their leaves but had higher $\mathrm{N}$ uptake than $\mathrm{cv}$. Xi 19. It may therefore, be presumed that the genotypes utilise $\mathrm{N}$ differently. While the spelt and emmer used it to produce more shoot biomass with the lower leaf $\mathrm{N}$ concentration, modern bread wheat seemed to produce less shoot biomass but with a higher leaf $\mathrm{N}$ concentration.

Figure 02: Representative root system architectural images of bread wheat (A) JB Diego (B) Xi 19 (C) Spelt Tauro (D) Spelt SB (E) Spelt Oberkulmer (F) Emmer 1 (G) Emmer 2 (H) Einkorn 1 (I) Einkorn 2 and (J) Einkorn 3 at 14 DAT in experiment 1 

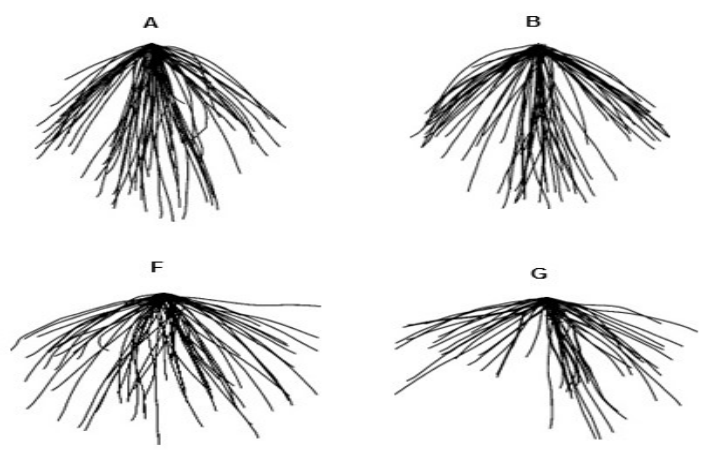
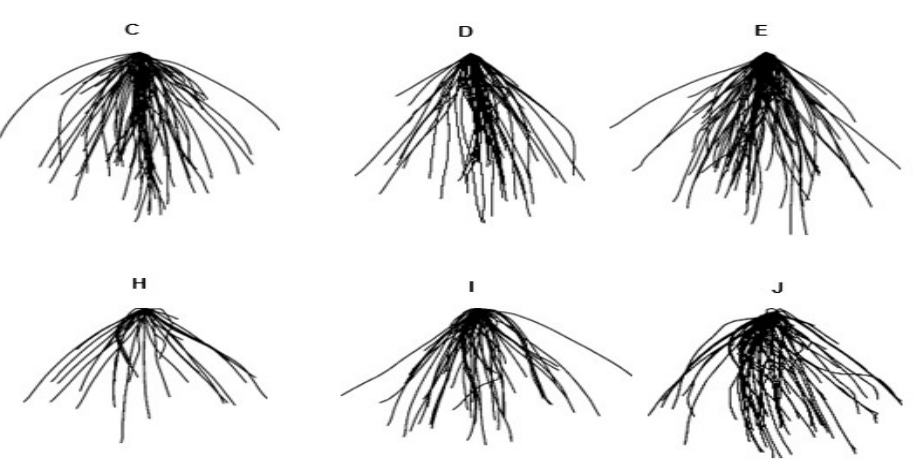

Figure 03: $\quad$ Root system architecture of bread wheat (A) JB Diego (B) Xi 19 (C) Spelt Tauro (D) Spelt SB (E) Spelt Oberkulmer (F) Emmer 1 (G) Emmer 2 (H) Einkorn 1 (I) Einkorn 2 and (J) Einkorn 3 at 14 DAT in experiment 1 . These images are produced by overlaying all RSA images of the replicates of 10 genotypes using Root Nav software $(n=10$ to 25$)$

Table 01: $\quad$ Number of tillers per plant, green area $\left(\mathrm{cm}^{2}\right.$ plant $\left.\mathrm{t}^{-1}\right)$ and biomass production $\left(\mathrm{g} \mathrm{plant}^{-1}\right)$ of the plant at 14, 23, 32 and 41 days after transplanting (DAT) in Experiment 2

\begin{tabular}{|c|c|c|c|c|c|c|c|c|}
\hline \multirow{2}{*}{ GT } & \multicolumn{4}{|c|}{ Number of tillers (plant ${ }^{-1}$ ) } & \multicolumn{4}{|c|}{ Green area $\left(\mathrm{cm}^{2}\right.$ plant $\left.{ }^{-1}\right)$} \\
\hline & 14 DAT & 23 DAT & 32 DAT & $41 \mathrm{DAT}$ & 14 DAT & 23 DAT & 32 DAT & $41 \mathrm{DAT}$ \\
\hline JB Diego & 9 & 23 & 31 & 59 & 151.57 & 365.37 & 471.59 & 1070.83 \\
\hline Xi 19 & 6 & 13 & 26 & 56 & 174.33 & 478.75 & 590.32 & 1252.82 \\
\hline Spelt Tauro & 7 & 19 & 22 & 35 & 247.85 & 646.67 & 647.62 & 740.53 \\
\hline Spelt SB & 8 & 26 & 88 & 87 & 242.59 & 694.02 & 1117.31 & 2277.46 \\
\hline Spelt Oberkulmer & 10 & 27 & 55 & 79 & 230.87 & 693.54 & 832.45 & 1922.62 \\
\hline Emmer 1 & 7 & 13 & 30 & 72 & 201.81 & 570.47 & 959.94 & 1427.81 \\
\hline Emmer 2 & 6 & 16 & 27 & 67 & 228.68 & 647.91 & 925.90 & 1408.47 \\
\hline Einkorn 1 & 7 & 14 & 22 & 36 & 88.86 & 196.96 & 200.52 & 453.73 \\
\hline Einkorn 2 & 5 & 9 & 16 & 26 & 35.85 & 54.21 & 91.82 & 159.61 \\
\hline Einkorn 3 & 7 & 7 & 17 & 37 & 88.41 & 146.69 & 230.75 & 359.47 \\
\hline $\operatorname{SED}(d f=18)$ & 0.71 & 2.71 & 5.66 & 8.70 & 33.722 & 59.504 & 67.001 & 269.707 \\
\hline P value & $<0.001$ & $<0.001$ & $<0.001$ & $<0.001$ & $<0.001$ & $<0.001$ & $<0.001$ & $<0.001$ \\
\hline
\end{tabular}

Table 02: $\quad$ Shoot biomass production $\left(\mathrm{g} \mathrm{plant}^{-1}\right)$ and nitrogen uptake $\left(\mathrm{gN} \mathrm{shoot}^{-1}\right)$ of the plant at 14 , 23, 32 and 41 days after transplanting (DAT) in Experiment 2.

\begin{tabular}{lcccccccc}
\hline & \multicolumn{3}{c}{ Shoot biomass $\left(\mathrm{g} \mathrm{plant}^{-1}\right)$} & \multicolumn{5}{c}{$\mathrm{N}_{\text {off }}\left(\mathrm{gN} \mathrm{shoot}^{-1}\right)$} \\
\cline { 2 - 9 } & 14 DAT & 23 DAT & 32 DAT & 41 DAT & 14 DAT & 23 DAT & 32 DAT & 41 DAT \\
\hline JB Diego & 0.79 & 2.35 & 3.56 & 8.61 & 0.04 & 0.09 & 0.14 & 0.36 \\
Xi 19 & 0.87 & 2.94 & 5.69 & 13.53 & 0.04 & 0.12 & 0.22 & 0.54 \\
Spelt Tauro & 1.19 & 3.78 & 6.11 & 6.01 & 0.06 & 0.14 & 0.19 & 0.20 \\
\hline
\end{tabular}




\begin{tabular}{lcccccccc}
\hline \multirow{2}{*}{ GT } & \multicolumn{4}{c}{ Shoot biomass $\left(\mathrm{g} \mathrm{plant}^{-1}\right)$} & \multicolumn{5}{c}{$\mathrm{N}_{\text {off }}\left(\mathrm{gN} \mathrm{shoot}^{-1}\right)$} \\
\cline { 2 - 8 } & 14 DAT & 23 DAT & 32 DAT & 41 DAT & 14 DAT & 23 DAT & 32 DAT & 41 DAT \\
\hline Spelt Oberkulmer & 1.10 & 3.71 & 6.63 & 16.16 & 0.06 & 0.15 & 0.23 & 0.63 \\
Emmer 1 & 0.95 & 3.10 & 7.26 & 13.03 & 0.05 & 0.12 & 0.26 & 0.47 \\
Emmer 2 & 1.08 & 3.81 & 7.45 & 15.77 & 0.05 & 0.14 & 0.28 & 0.54 \\
Einkorn 1 & 0.50 & 1.27 & 1.90 & 4.60 & 0.02 & 0.04 & 0.06 & 0.09 \\
Einkorn 2 & 0.20 & 0.40 & 0.83 & 1.41 & 0.01 & 0.01 & 0.02 & 0.04 \\
Einkorn 3 & 0.49 & 1.29 & 2.38 & 3.58 & 0.02 & 0.04 & 0.07 & 0.10 \\
SED $(d f=18)$ & 0.13 & 0.29 & 0.61 & 2.72 & 0.01 & 0.01 & 0.03 & 0.11 \\
P value & $<0.001$ & $<0.001$ & $<0.001$ & $<0.001$ & $<0.001$ & $<0.001$ & $<0.001$ & $<0.001$ \\
\hline
\end{tabular}

The highest shoot N\% was recorded in bread wheat cv. JB Diego; 5.06 and 4.14 at 23 and 41 DAT, respectively $(P<0.001)$. Einkorn 2 recorded the lowest shoot N\% during the experiment. Table 2 shows shoot $\mathrm{N}$ uptake of the ten genotypes throughout the experimental period. The ranking of the genotypes forN uptake at 41 DAT was spelt cv. SB $>$ spelt cv. Oberkulmer $>$ bread wheat $\mathrm{cv}$. Xi 19 and emmer $2>$ emmer $1>$ bread wheat $\mathrm{cv}$. JB Diego $>$ spelt cv. Tauro $>>$ einkorn $3>$ einkorn $1>$ einkorn 2.

The heighest total root length was recorded in spelt cv. SB and Oberkulmer than other genotypes throughout the experiment $2(P<0.001)$ (Figure 04A). All einkorn genotypes showed very weak root growth and produced fewer roots than the other genotypes. The total root length of emmer and bread wheat was in between spelt and einkorn. The highest root biomass (Figure 04B) of the genotypes was recorded in spelt cv. SB at 32 and 41 DAT (87\% and $81 \%$ higher than the lowest value produced by einkorn 2 , respectively). The ranking of the genotypes for

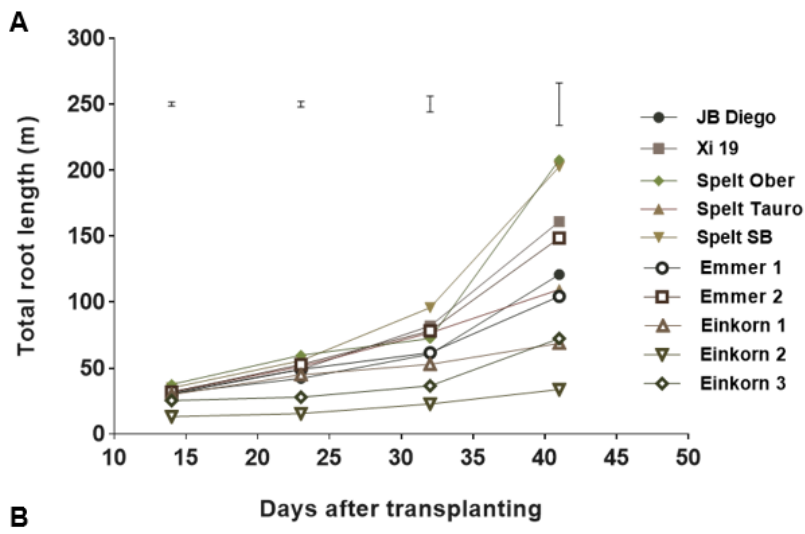

root biomass production at 41 DAT was spelt cv. $\mathrm{SB}>$ spelt cv. Oberkulmer $>$ bread wheat cv. Xi $19>$ emmer $2>$ bread wheat cv. JB Diego $>$ spelt cv. Tauro $>$ emmer $1>$ einkorn $1>$ einkorn $3>$ einkorn 2.

Similar to the results of total root length, the highest root volume (Figure 05) was observed in spelt genotypes and the lowest values in einkorn. Average root diameter was high in emmer genotypes and lower in einkorn, suggesting that emmer has thicker roots than all other genotypes. Specific root length (SRL) was high in einkorn 2 and low in emmer genotypes. SRL of all genotypes decreased over time, indicating younger plants had thinner roots.

Root length was recorded in different diameter $(\mathrm{mm})$ classes where lower diameters represent more lateral roots and the higher diameter classes represent more seminal and nodal roots. Length of very fine roots (LVFR; $<0.5 \mathrm{~mm}$ diameter) represented $78 \%$ to $85 \%$ of the total root length at 41 DAT, depending on the species.

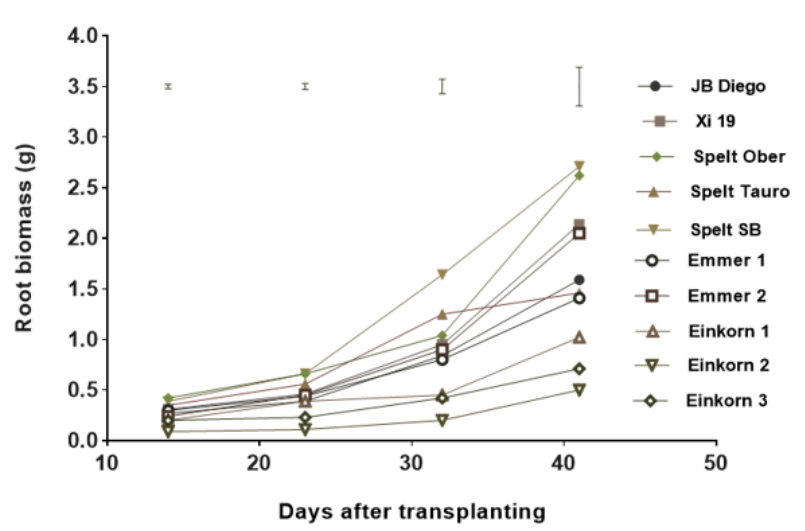

Figure 04: (A) Total root length (B) root biomass of the genotypes at 14 DAT in Experiment 2. Error bars represent the SED of the genotypes at $P<0.001(d f=18)$. 


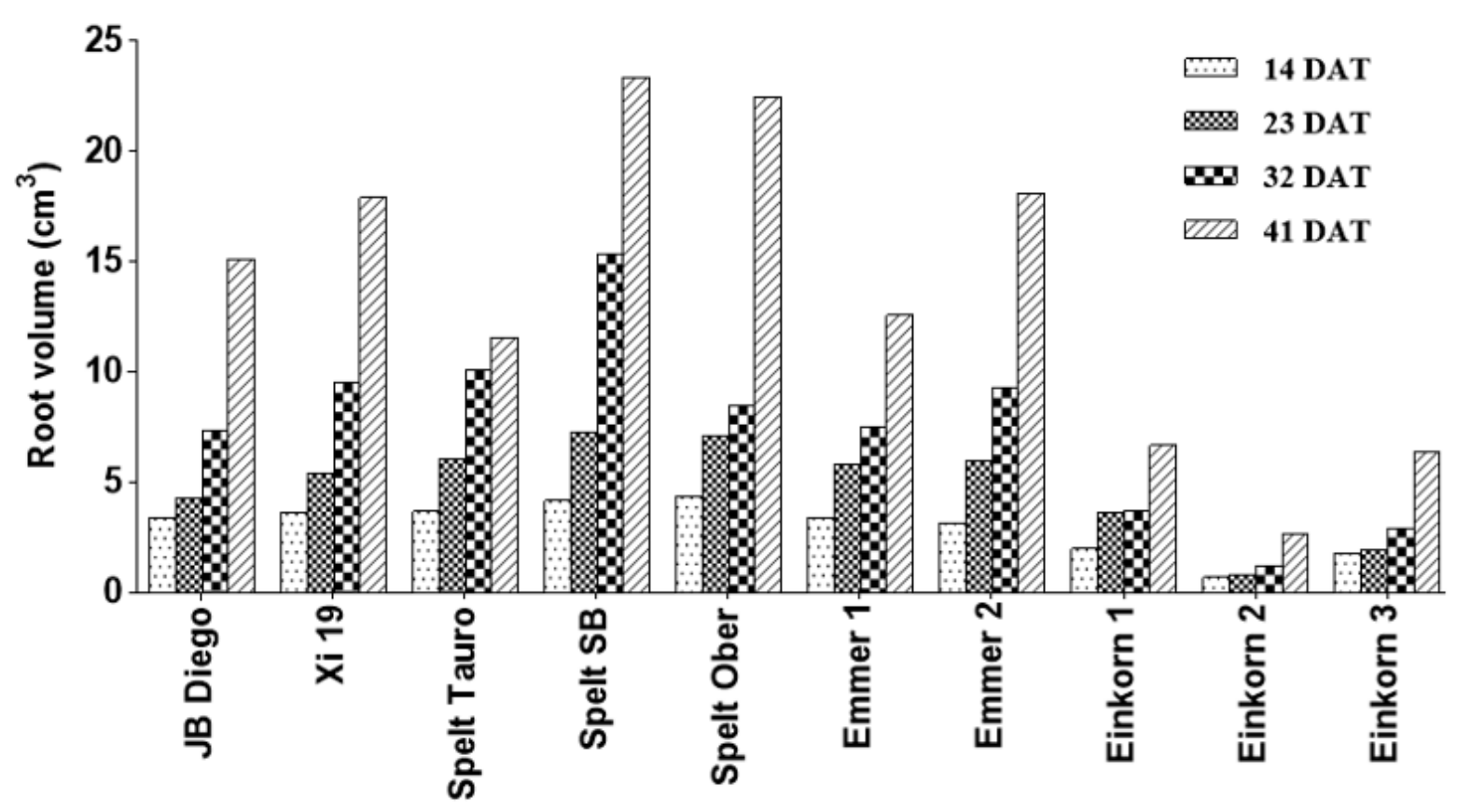

Figure 05: Root volume of the genotypes at 14, 23, 32 and 41DAT in Experiment 2. SED for GT at $14,23,32$ and 41 DAT was $0.49,0.56,1.69$ and 3.68, respectively $(d f=18)$.

Spelt genotypes had the highest root elongation rate (RER) and einkorn the lowest. RER of spelt was higher than bread wheat by $23 \%$, while emmer and einkorn genotypes had lower RER than bread wheat by $11 \%$ and $142 \%$, respectively. Nitrogen uptake efficiency of roots $\left(\mathrm{NUpE}_{\mathrm{R}}\right)$ was significantly different among genotypes throughout the experiment and mean across all sampling dates, the highest value was recorded in emmer and lowest in einkorn $(P<0.001)$ (Table $03)$. The average $\mathrm{NUpE}_{\mathrm{R}}$ of emmer at $41 \mathrm{DAT}$ was $25 \%, 35 \%$ and $166 \%$ higher than bread wheat, spelt and einkorn, correspondingly. The highest specific absorption rate of roots $\left(S_{A B} R_{N}\right)$ was recorded in emmer 1 both for root biomass and total root length but there is no significant difference between Spelt cv. SB and emmer 1 $(P<0.001)$ (Table 03).

The green area of the plant at all sampling dates had a positive and strong relationship with respective shoot $\mathrm{N}$ uptake $(\mathrm{r}=0.97, P<0.001)$. A similar relationship was observed between shoot biomass and $\mathrm{N}$ uptake of the shoot $(\mathrm{r}=0.96$, $P<0.001)$. Nitrogen uptake efficiency of roots $\left(\mathrm{NUpE}_{\mathrm{R}}\right)$ explained green area $(50 \%$ to $66 \%)$ and shoot biomass production (53\% to $74 \%$ ) in all genotypes throughout the experiment. The number of tillers explained $70 \%$ of the variation in total root length $(P<0.001)$ and observed variation of green area production per plant is associated with tiller production $(\mathrm{r}=0.90, P$ $<0.001$ ) and therefore, total root length of the plant had a strong relationship with green area production $(\mathrm{r}=0.87, P<0.001)$ or number of leaves/ number of tillers per plant at 41 DAT.

Total root length and root length density explained $90 \%$ of $\mathrm{N}$ uptake of the shoot at 41 DAT. The relationship between root volume and $\mathrm{N}$ uptake of the shoot was strong $(\mathrm{r}=0.94, P<0.001)$. Root biomass explained $93 \%$ of $\mathrm{N}$ uptake of the shoot $(P<0.001)$. A close relationship was found between $\mathrm{N}$ uptake and length of very fine roots, and more than $88 \%$ of the variation in $\mathrm{N}$ uptake was explained by this diameter class $(P<0.001)$.

In experiment 3, above-ground biomass (AGB) and grain yield were significantly different between genotypes $(P<0.001)$ and $\mathrm{N}$ level $(P<$ $0.01)$ at maturity. Emmer 2 had the highest AGB at both $\mathrm{N}$ levels and einkorn the lowest. The most grain yield was observed in bread wheat cv. JB Diego for LN and HN conditions (Table 04).

Plants treated with $\mathrm{HN}$ had greater N\% in the straw, chaff and grain than LN plants $(P<0.05)$. Genotypes differed significantly $(P<0.001)$ although there was no significant interaction 
between genotype and $\mathrm{N}$ level. Spelt cv. Oberkulmer recorded the lowest straw N\% at 0.42 and 0.86 for $\mathrm{LN}$ and $\mathrm{HN}$ treatments, respectively, while einkorn 3 recorded the highest values for both $\mathrm{N}$ levels (Table 05). Chaff N\% varied between 0.33 to 1.04 for $\mathrm{LN}$ and 0.88 to 1.59 for $\mathrm{HN}$ plants. Highest grain N\% was recorded in einkorn 2 in both $\mathrm{LN}$ (3.45) and HN (3.99). Bread wheat cv. JB Diego recorded the lowest $\mathrm{N} \%$ of the grain of 1.40 and 2.19 for $\mathrm{LN}$ and $\mathrm{HN}$, respectively.

Table 03: $\quad$ Root $N$ uptake efficiency (\%) at 14, 23, 32 and 41 days after transplanting (DAT) and the specific absorption rate of $\mathrm{N}$ based on root biomass $\left(\mathrm{mg} \mathrm{g}^{-1}\right.$ root day $\left.^{-1}\right)$ and root length $\left(\mathrm{mg} \mathrm{m}^{-1}\right.$ root $\left.\mathrm{day}^{-1}\right)$ of the plants during 14 DAT to 41 DAT in Experiment 2

\begin{tabular}{lcccccc}
\hline & \multicolumn{3}{c}{ Root N uptake efficiency (\%) } & \multicolumn{2}{c}{ Specific absorption rate } \\
\cline { 2 - 7 } GT & 14 DAT & 23 DAT & 32 DAT & 41 DAT & mg g $^{-1}$ & mg m $^{-1}$ \\
\cline { 5 - 7 } & 15.33 & 22.27 & 16.59 & 22.17 & 15.58 & 0.18 \\
JB Diego & 14.34 & 26.40 & 23.09 & 24.87 & 18.88 & 0.23 \\
Xi 19 & 16.56 & 26.14 & 15.30 & 15.26 & 7.43 & 0.09 \\
Spelt Tauro & 14.04 & 23.18 & 19.34 & 25.94 & 19.37 & 0.24 \\
Spelt SB & 13.17 & 22.29 & 22.89 & 23.99 & 16.94 & 0.21 \\
Spelt Oberkulmer & 15.65 & 27.41 & 32.94 & 33.54 & 22.05 & 0.27 \\
Emmer 1 & 21.58 & 32.43 & 30.87 & 25.37 & 20.25 & 0.23 \\
Emmer 2 & 11.83 & 10.60 & 13.29 & 8.81 & 5.38 & 0.05 \\
Einkorn 1 & 9.06 & 10.47 & 11.65 & 9.60 & 5.32 & 0.05 \\
Einkorn 2 & 12.35 & 17.91 & 16.87 & 14.79 & 7.27 & 0.06 \\
Einkorn 3 & 1.83 & 3.09 & 2.35 & 3.46 & 2.72 & 0.04 \\
SED (df = 18) & $<0.001$ & $<0.001$ & $<0.001$ & $<0.001$ & $<0.001$ & $<0.001$ \\
P & & & & &
\end{tabular}

Table 04: Above-ground biomass $\left(\mathrm{g} \mathrm{plant}^{-1}\right)$ and grain yield (g plant-1) of the plant at maturity in Experiment 3 at $\mathrm{LN}$ (an equivalent rate of $50 \mathrm{~kg} \mathrm{~N} \mathrm{ha}^{-1}$ ) and $\mathrm{HN}$ (an equivalent rate of $200 \mathrm{~kg} \mathrm{~N} \mathrm{ha}^{-1}$ )

\begin{tabular}{lcccc}
\hline \multirow{2}{*}{ GT } & \multicolumn{2}{c}{ Above-ground biomass $\left(\right.$ g plant $\left.^{-1}\right)$} & \multicolumn{2}{c}{ Grain yield $\left(\right.$ g plant $\left.^{-1}\right)$} \\
\cline { 2 - 5 } & LN & HN & LN & HN \\
\hline JB Diego & 36.03 & 50.98 & 12.47 & 20.59 \\
Xi 19 & 32.27 & 50.91 & 11.71 & 18.89 \\
Spelt Tauro & 30.37 & 44.83 & 8.94 & 12.60 \\
Spelt SB & 32.53 & 60.42 & 8.26 & 16.03 \\
Spelt Oberkulmer & 33.57 & 49.43 & 5.42 & 12.35 \\
Emmer 1 & 37.75 & 56.40 & 8.28 & 14.04 \\
Emmer 2 & 41.99 & 61.81 & 10.10 & 13.26 \\
Einkorn 1 & 17.55 & 39.38 & 3.36 & 3.55 \\
Einkorn 2 & 12.56 & 28.63 & 1.46 & 3.27 \\
Einkorn 3 & 18.34 & 25.44 & 2.18 & $1.957(36)^{* * *}$ \\
SED ; GT $(d f)$ & \multicolumn{3}{c}{$3.541(36)^{* * *}$} & \multicolumn{2}{c}{$0.326(2)^{* *}$} \\
N $(d f)$ & $0.835(2)^{* *}$ & $2.646(36.9)^{\mathrm{NS}}$ \\
GT x N $(d f)$ & $4.823(37.6)^{\mathrm{NS}}$ & & \\
\hline
\end{tabular}

*** Significant at $P<0.001,{ }^{* *}$ significant at $P<0.01$, *significant at $P<0.05$, NS - Not significant 
Table 05: $\quad$ Straw N\%, chaff N\% and grain N\% of the genotypes at maturity in Experiment 3 at LN (an equivalent rate of $50 \mathrm{~kg} \mathrm{~N} \mathrm{ha}^{-1}$ ) and $\mathrm{HN}$ (an equivalent rate of $200 \mathrm{~kg} \mathrm{~N} \mathrm{ha}^{-1}$ )

\begin{tabular}{llllllc}
\hline \multirow{2}{*}{ GT } & \multicolumn{2}{c}{ Straw N\% } & \multicolumn{2}{c}{ Chaff N\% } & \multicolumn{2}{c}{ Grain N\% } \\
\cline { 2 - 7 } & LN & HN & LN & HN & LN & HN \\
\hline JB Diego & 0.52 & 1.33 & 0.59 & 1.50 & 1.40 & 2.19 \\
Xi 19 & 0.47 & 1.21 & 0.42 & 1.22 & 1.42 & 2.28 \\
Spelt Tauro & 0.63 & 1.14 & 0.44 & 0.88 & 2.34 & 3.20 \\
Spelt SB & 0.70 & 0.89 & 0.68 & 1.59 & 2.20 & 3.27 \\
Spelt Ober & 0.42 & 0.86 & 1.04 & 1.35 & 3.08 & 3.62 \\
Emmer 1 & 0.53 & 1.11 & 0.33 & 1.02 & 2.42 & 3.26 \\
Emmer 2 & 0.53 & 0.86 & 0.40 & 1.23 & 2.27 & 3.43 \\
Einkorn 1 & 0.91 & 1.43 & 0.69 & 1.39 & 2.86 & 3.67 \\
Einkorn 2 & 0.76 & 1.32 & 0.72 & 1.40 & 3.17 & 3.89 \\
Einkorn 3 & 0.95 & 2.13 & 0.95 & 1.44 & 3.45 & 3.99 \\
SED ; GT $(d f)$ & $0.190(36)^{* *}$ & $0.135(36)^{* * *}$ & $0.176(36)^{* * *}$ \\
N $(d f)$ & $0.81(2)^{*}$ & $0.104(2)^{*}$ & $0.098(2)^{*}$ \\
GT x N $(d f)$ & $0.268(36.9)^{\mathrm{NS}}$ & $0.201(21.6)^{\mathrm{NS}}$ & $0.256(32.1)^{\mathrm{NS}}$ \\
\hline
\end{tabular}

*** Significant at $P<0.001,{ }^{* *}$ significant at $P<0.01$, *significant at $P<0.05$, NS - Not significant

NUpE of the genotypes was between 0.20 to 0.54 for $\mathrm{LN}$ and 0.16 to 0.34 for $\mathrm{HN}$ plants. The highest NUpE was recorded in emmer species followed by spelt, bread wheat and then einkorn $(P<0.001)$ (Figure 06) and always higher at LN. However, no interaction was observed between genotype and $\mathrm{N}$ level.

\section{DISCUSSION}

The development of root systems which promote $\mathrm{N}$ uptake is important (Delmer, 2005; Foulkes et al., 2009; Gaju et al., 2011) considering the significant impact of artificial $\mathrm{N}$ fertiliser on cost of production and its detrimental effects on the environment (Conley et al., 2009; Vitousek et al., 2009; Dourado-Neto et al., 2010).

In Experiment 1 the ancient wheat genotypes, together with bread wheat, exhibited substantial variation in the number of seminal roots which ranged from 3.76 to 5.27 , compared to Gregory et al. (1978) who reported that, on average, the winter wheat grown in temperate weather conditions produced six seminal roots. The greatest number of seminal roots was recorded in emmer 2, suggesting that emmer has the potential to develop a strong root system at the early stages of crop growth. The total root length of the seedling was also high in emmer when compared to all other genotypes. Therefore, it can be proposed that, mature emmer will develop a horizontally grown root system enabling it to uptake more fertiliser $\mathrm{N}$ from the top layers of the soil before it is transferred to deeper layers of the soil horizon.

The seminal root tip angle of emmer 2 was wider than the other ancient wheat genotypes suggesting the development of a wider root system. Supporting the above suggestion, emmer 2 recorded the maximum width of the root system within 14 DAT. Spelt and bread wheat genotypes had a narrow tip angle of seminal roots and deeper root systems when compared to emmer and einkorn. The current results showed some consistency with previous investigations by Nakomoto and Oyangi (1994) who, based on the variation of the angular spread of seminal roots of Japanese wheat germplasm, found that genotypes with narrower angles of seminal 
roots ended up with deep root systems while shallow root systems had much wider angle and horizontally grown seminal roots. Liao et al. (2004) suggested that wheat crops with a large root biomass and a deeper root system might be more efficient in recovering soil N. In this study, emmer species recorded the highest uptake efficiency of fertiliser $\mathrm{N}$ at maturity although bread wheat seedlings produced the deepest roots. This is in partial agreement with previous investigations that the soil $\mathrm{N}$ uptake of modern, high yielding bread wheat varieties, are considerably lesser efficient than their ancestors (Foulkes et al., 1998), though einkorn recorded the lowest NUpE in present study.

The highest average length of the seminal roots was produced by spelt cv. Oberkulmer. The average length of the seminal roots had a promising relationship with the maximum depth of the root system, where bread wheat and spelt had deeper seedling root systems than emmer and einkorn. Therefore, it can be predicted that the mature root systems of emmer and einkorn will be shallower than those of spelt and bread wheat. Lateral root production was significantly different between genotypes. Genotypes of einkorn did not produce any lateral roots at 14 DAT, illustrating their inability to develop a strong root system at early growth stages, leading to a poor seedling growth. Plants possessing dense root systems with many lateral branches and root hairs are better adapted to acquire nutrients in the soil due to their higher root surface area (Gahoonia et al., 2007). Large root biomass, high root length density and seminal roots with shallow growth angles are among the root traits for a proposed $\mathrm{N}$ efficient ideotype capable of efficient $\mathrm{N}$ acquisition with early root vigour (Lynch, 2013). These traits are well suited to capture $\mathrm{N}$ at deeper soil layers since $\mathrm{NO}_{3}^{-}$moves rapidly to deeper layers of the soil profile during the growing season (Lynch, 2013).

According to the results of experiment 2, spelt cv. SB and Oberkulmer recorded the highest total root length, root volume, root length density, root diameter, root biomass and root elongation rate. However, there is an effect of nodal roots on the size of the root systems. Spelt produced a very large number of tillers in the vegetative phase when compared to all other genotypes and had a strong positive correlation between root length. Previous findings suggested that the number of nodal roots of wheat has a strong linear relationship with the number of leaves on the culm (Gregory et al., 1978), so that genotypes with vigorous early growth and tillering capacity may develop more leaves, hence more nodal roots.

Liao et al. (2004) reported that early uptake of $\mathrm{N}$ in wheat is controlled by fast and early crop growth. In agreement, in the current study, the highest plant biomass production was recorded in spelt species at early harvesting points suggesting its ability to capture $\mathrm{N}$ at early plant development. Regression of shoot biomass and root biomass revealed a strong positive linear relationship, thus it was presumed that higher root biomass translated into higher shoot biomass because bigger root systems were able to acquire more nutrients and support more shoot biomass. However, Gallais and Coque (2005) were of the opinion that a large root system would compete for assimilates, resulting in less assimilate for grain production. Similarly, Passioura (1983) also argued that smaller root systems would increase resource use efficiency by making more assimilate available for shoots. Waines and Ehdaie (2007) found that the root systems of the ancient genotypes are larger than modern bread wheat cultivars. This may be due to the effect of Rht genes on root growth (Wojciechowski et al., 2009). In contrast, our results showed that, while emmer and spelt had large root systems, einkorn produced the least amount of biomass, owing to the small root size that drastically reduced resource capturing capacity.

Nielsen \& Schjorring (1983) and Egle et al. (1999) observed a significant variation between cereal genotypes on specific root length and root length density. In our study, einkorn genotypes obtained the highest specific root length, indicating it had the thinnest roots, and in fact, $84 \%$ of the total root length was $\leq 0.5 \mathrm{~mm}$ in diameter. Bread wheat cv. Xi 19 and emmer genotypes had the lowest specific root length and thus, thicker roots compared to the other species. Root biomass was negatively correlated to specific root length, plants with higher root biomass tended to have 
thicker roots compared to plants with smaller root biomass. As root biomass increased, greater quantities of the root length were partitioned to roots with thicker diameters.

There was a negative relationship between the specific root length and $\mathrm{N}$ uptake. Specific root length was found to be highest in einkorn 2 which had the least N. Additionally, total root length of einkorn 2 was significantly lower than all other genotypes. The specific root length is not only dependent on finer roots but also root tissue density and root biomass. In contrast, a study by Eissenstat (1992) concluded that plants with high values of Specific root length generally produce higher root length density and therefore, capture resources more efficiently. However, in the current study, thicker roots increased the capacity of the root system to capture $\mathrm{N}$. This can partly be explained by the fact that thicker roots may have a larger surface area due to root hairs for absorption of nutrients, hence higher levels of $\mathrm{N}$ uptake. King et al. (2003) affirmed that decreasing SRL would confer greater $\mathrm{N}$ capture and yield under low $\mathrm{N}$ availability.

Spelt species had the highest root elongation rate, $23 \%$ more than bread wheat, while emmer hada lower root elongation rate than bread wheat. Burgos et al. (2001) reported that spelt species have higher growth rates and better early seedling hardiness compared to modern bread wheat. Since the seedling stage is a critical period for young plants, vigorous plants with fast-growing roots enable the plant to cope with abiotic and biotic stress. root elongation rate was positively correlated with $\mathrm{N}$ uptake indicating that fastgrowing roots ensure optimum surface area and rooting volume for nutrient capture. This trait is particularly desirable for wheat crops which have been sown in winter, a period with a high risk of nitrate leaching, especially in sandy soils (Gastal and Lemaire, 2002). The highest $\mathrm{N}$ uptake was recorded in emmer and spelt throughout the experiment and a similar trend was observed in terms of $\mathrm{NUpE}_{\mathrm{R}}$. However, $\mathrm{NUpE}_{\mathrm{R}}$ of emmer and spelt, on average across all harvesting points, was not significantly different.

In experiment 3 , there was a negative relationship between grain $\mathrm{N} \%$ and the grain yield, similar to the findings of Oury et al. (2003) and Kade et al. (2005) who found a negative relationship between grain protein content and grain yield in wheat. This phenomenonis commonly identified as the $\mathrm{N}$ dilution effect. NUpE of the mature plant was found to be higher under LN conditions than HN conditions. Ortiz-Monasterio et al. (1997), LeGouis et al. (2000) and Gaju et al. (2011) also reported that $\mathrm{NUpE}$ in $\mathrm{LN}$ was greater than in HN treated plants. The overall result of these three experiments emphasises the importance of variation in root architectural traits in ancient wheat species and the relationships between early root architectural traits and NUpE at maturity.

\section{CONCLUSIONS}

Root architecture of wheat species used in the study varied significantly at the seedling stage. Total root length, root volume, root biomass, root length density and root diameter had strong relationships with shoot $\mathrm{N}$ uptake of the plants at vegetative growth phase hence improved green area, shoot biomass production and $\mathrm{N}$ uptake. At maturity, NUpE showed a negative relationship with $\mathrm{N}$ supply. A significant difference for $\mathrm{NUpE}$ was observed between ploidy levels, with a higher value for tetraploid wheat than hexaploid or diploid wheat. These findings suggest that as bread wheat was selected for high yield, favourable root traits related to $\mathrm{NUpE}$ were neglected. Emmer has more favourable root traits that are related to $\mathrm{NUpE}$ despite genetic background as a tetraploid plant. Further studies are needed to identify QTLs associated with $\mathrm{NUpE}$ and root architectural traits of emmer. However, emmer has already been used in wheat breeding programmes since it serves as a gene reservoir for disease resistance and drought tolerance traits. Likewise, favourable root traits in emmer related to $\mathrm{NUpE}$ could be introduced to bread wheat through the direct crossing or creating synthetic wheat.

\section{ACKOWLEDGEMENTS}

This study was funded by the Commonwealth Scholarship Commission and the University of Nottingham, United Kingdom. 


\section{REFERENCES}

Atkinson, J.A., Wingen, L. U., Griffiths, M., Pound, M. P., Gaju, O., Foulkes, M. J., Le Gouis, J., Griffiths, S., Bennett, M.J., King, J. and Wells, D. M.(2015). Phenotyping pipeline reveals major seedling root growth QTL in hexaploid wheat. Journal of Experimental Botany. 66, 2283-2292. https://doi.org/10.1093/jxb/erv006

Barraclough, P. B., Weir, A. H. and Kuhlmann, H. (1991). Factors affecting the growth and distribution of winter wheat roots under UK field conditions. Developments in Agricultural and Managed Forest Ecology. 24, 410-441. https://doi.org/10.1016/B978-0-444-89104-4.50057-8

Barraclough, P. B., Howarth, J. R., Jones, J., Lopez-Bellido, R., Parmar, S., Shepherd, C. E. and Hawkesford, M. J. (2010) Nitrogen efficiency of wheat: Genotypic and environmental variation and prospects for improvement. European Journal of Agronomy. 33, 1-11. https://doi. org/10.1016/j.eja.2010.01.005

Beatty, P. H., Anbessa, Y., Juskiw, P., Carroll, R. T., Wang, J. and Good, A. G.(2010). Nitrogen use efficiencies of spring barley grown under varying nitrogen conditions in the field and growth chamber. Annals of Botany. 105, 1171-1182. https://doi.org/10.1093/aob/mcq025

Bowman, D. C., Devitt, D. A, Engelke, M. C. and Rufty, T. W.(1998) Root Architecture Affects Nitrate Leaching from Bentgrass Turf. Crop Science. 38, 1633-1639. https://doi.org/10.2135/ cropsci1998.0011183X003800060036x

Bowman, D. C., Cherney, C. T. and Rufty, T. W Jr.(2002). Fate and transport of nitrogen applied to six warm-season turfgrasses. Crop Science. 42, 833-841. https://doi.org/10.2135/cropsci2002.8330

Brady, D. J., Gregory, P. J. and Fillery, I. R. P.(1993). The contribution of different regions of the seminal roots of wheat to uptake of nitrate from soil. Plant Nutrition - from Genetic Engineering to Field Practice. Pp, 169-172.

Burgos, S. M., Messmer, M. M., Stamp, P. and Schmid, J. E.(2001). Flooding tolerance of spelt (Triticum spelta L.) compared to wheat (Triticum aestivum L.) - A physiological and genetic approach. Euphytica. 122, 287-295. https://doi.org/10.1023/A:1012945902299

Conley, D. J., Paerl, H. W. and Howarth, R. W.(2009). Controlling eutrophication: nitrogen and phosphorus. Science. 323, 1014-1015.

Dawson, C. J. and Hilton, J. (2011). Fertiliser availability in a resource-limited world: Production and recycling of nitrogen and phosphorus. Food Policy. 36, S14-S22. https://doi.org/10.1016/j. foodpol.2010.11.012

Delmer, D.(2005). Agriculture in the developing world: Connecting innovations in plant research to downstream applications. Proceedings of the National Academy of Sciences of the United States of America. 102, 15739-46.

Department for Environment, Food \& Rural Affairs (2012). The British Survey of Fertiliser Practice: Fertiliser use on farm crops for crop year 2011. Crop Statistics

Dourado-Neto, D., Powlson, D., Abu-Bakar, R., Bacchi, O. O. S., Basanta, M. V., Cong, P., Keerthisinghe, G., Ismaili, M., Rahman, S. M., Reichardt, K., Safwat, M. S. A., Sangakkara,R., Timm, L. C., Wang, J. Y., Zagal, E. and Van- Kessel, C.(2010). Multiseason recoveries of organic and inorganic nitrogen-15 in tropical cropping systems. Soil Science Society of America Journal. 74(01), 139-152. https://doi.org/10.2136/sssaj2009.0192 
Eissenstat, D.M.(1992). Costs and benefits of constructing roots of small diameter. Journal of Plant Nutrition. 15, 763-782. https://doi.org/10.1080/01904169209364361

Egle, K., Manske, G., R“omer, W. and Vlek, P. L. G.(1999). Improved phosphorus efficiency of three new wheat genotypes from CIMMYT in comparison with an older Mexican variety. Journal of Plant Nutrition and Soil Science. 162, 353-358. https://doi.org/10.1002/(SICI)15222624(199906)162:3<353::AID-JPLN353>3.0.CO;2-A

Ehdaie, B., Merhaut, D. J., Ahmadian, S., Hoops, A. C., Khuong, T., Layne, A. P. and Waines, J. G.(2010). Root System Size Influences Water-Nutrient Uptake and Nitrate Leaching Potential in Wheat. Journal of Agronomy and Crop Science. 196, 455-466. https://doi.org/10.1111/j.1439037X.2010.00433.X

Foulkes, M. J., Sylvester- Bradley, R. and Scott, R. K.(1998). Evidence for differences between winter wheat cultivars in acquisition of soil mineral nitrogen and uptake and utilization of applied fertilizer nitrogen. The Journal of Agricultural Science. 130, 29-44. https://doi.org/10.1017/ S0021859697005029

Foulkes, M. J., Hawkesford, M. J., Barraclough, P. B., Holdsworth, M. J., Kerr, S., Kightley, S. and Shewry, P. R.(2009) Identifying traits to improve the nitrogen economy of wheat: Recent advances and future prospects. Field Crops Research. 114, 329-342. https://doi.org/10.1016/j. fcr.2009.09.005

Gahoonia, T.S., Ali, R., Malhotra, S.R., Jahoor, A. and Rahman, M.M. (2007), Variation in Root Morphological and Physiological Traits and Nutrient Uptake of Chickpea Genotypes. Journal of Plant Nutrition. 30, 829-841. https://doi.org/10.1080/15226510701373213

Gaju, O., Allard, V., Martre, P., Snape, J. W., Heumez, E., Le-Gouis, J., Moreau, D., Bogard, M., Griffiths, S., Orford, S., Hubbart, S. and Foulkes, M. J.(2011). Identification of traits to improve the nitrogen-use efficiency of wheat genotypes. Field Crops Research. 123, 139-152. https:// doi.org/10.1016/j.fcr.2011.05.010

Gallais, A. and Coque, M.(2005). Genetic variation and selection for nitrogen use efficiency in maize: a synthesis. Maydica. 50, 531-537.

Garnett, T., Vanessa, C. and Kaiser, B. N.(2009). Root based approaches to improving nitrogen use efficiency in plants. Plant Cell Environment. 32, 1272-1283. https://doi.org/10.1111/j.13653040.2009.02011.x

Gastal, F. and Lemaire, G.(2002). N uptake and distribution in crops: an agronomical and ecophysiological perspective. Journal of Experimental Botany. 53, 789-799. https://doi. org/10.1093/jexbot/53.370.789

Gregory, P. J., Mcgowan, M., Biscoe, P. V. and Hunter, B.(1978). Water relations of winter wheat .1. Growth of root system. Journal of Agricultural Science. 91, 91-102.DOI: https://doi. org/10.1017/S0021859600056653

Hackett, C.(1969). A study of the root system of barley II. Relationships between root dimensions and nutrient uptake. New phytologist. 68, 1023-1030. https://doi.org/10.1111/j.1469-8137.1969. tb06502.x 
Hirel, B., Le Gouis, J., Ney, B. and Gallais, A.(2007) The challenge of improving nitrogen use efficiency in crop plants: towards a more central role for genetic variability and quantitative genetics within integrated approaches. Journal of Experimental Botany. 58(9), 2369-2387. https://doi.org/10.1093/jxb/erm097

Kade, M., Barneix, A. J., Olmos, S. and Dubcovsky, J.(2005). Nitrogen uptake and remobilization in tetraploid 'Langdon' durum wheat and a recombinant substitution line with the high grain protein gene Gpc-B1. Plant Breeding. 124(4), 343-349. https://doi.org/10.1111/j.14390523.2005.01110.x

King, J., Gay, A., Sylvester-Bradley, R., Bingham, I., Foulkes, J., Gregory, P. and Robinson, D.(2003). Modelling cereal root systems for water and nitrogen capture: Towards an economic optimum. Annals of Botany. 91, 383-393. https://doi.org/10.1093/aob/mcg033

Kraiser, T., Gras, D. E., Gutierrez, A. G., Gonzalez, B. and Gutierrez, R. A.(2011). A holistic view of nitrogen acquisition in plants. Journal of Experimental Botany. 62, 1455-1466. https://doi. org/10.1093/jxb/erq425

Le Gouis, J., Béghin, D., Heumez, E. and Pluchard, P.(2000). Genetic difference for nitrogen uptake and nitrogen utilisation efficiencies in winter wheat. European Journal of Agronomy. 12, $163-$ 173. https://doi.org/10.1016/S1161-0301(00)00045-9

Liao, M. T., Fillery, I. R. P. and Palta, J. A.(2004). Early vigorous growth is a major factor influencing nitrogen uptake in wheat. Functional Plant Biology. 31, 121-129. https://doi.org/10.1071/ FP03060

Liao, M., Palta, J. A. and Fillery, I. R. P.(2006). Root characteristics of vigorous wheat improve early nitrogen uptake. Australian Journal of Agricultural Research. 57, 1097-1108. https://doi. org/10.1071/AR05439

Liu, J., Li, J., Chen, F., Zhan, F., Ren, T., Zhuang, Z. and Mi, G.(2009). Mapping QTLs for root traits under different nitrate levels at the seedling stage in maize (Zea mays L.). Plant and Soil. 305, 253-265. https://doi.org/10.1007/s11104-008-9562-z

Lynch, J. P. and Brown, K. M.(2012). New roots for Agriculture: exploiting the root phenome. Philosophical Transactions of the Royal Society of London. Series B, Biological Sciences. 367, 1598-1604. https://doi.org/10.1098/rstb.2011.0243

Lynch, J. P.(2013). Steep, cheap and deep: an ideotype to optimize water and N acquisition by maize root systems. Annals of Botany. 112, 347-357. https://doi.org/10.1093/aob/mcs293

Manschadi, A. M., Hammer, G. L., Christopher, J. T. and deVoil, P.(2008). Genotypic variation in seedling root architectural traits and implications for drought adaptation in wheat (Triticum aestivum L.). Plant and Soil. 303, 115-129. https://doi.org/10.1007/s11104-007-9492-1

Nakomoto, T. and Oyanagi, A.(1994). The direction of growth of seminal roots of Triticum aestivum L. and experimental modification thereof. Annals of Botany. 73, 363-367. https://doi.org/10.1006/ anbo.1994.1045

Nielsen, N. E. and Schjørring, J. K.(1983). Efficiency and kinetics of phosphorus uptake from soil by various barley genotypes. Plant and Soil. 72, 225-230. https://doi.org/10.1007/978-94-0096836-3_17 
Ortiz-Monasterio, J. I., Sayre, K. D., Rajaram, S. and McMahon, M.(1997). Genetic progress in wheat yield and nitrogen use efficiency under four nitrogen rates. Crop Science. 37, 898-904. https://doi.org/10.2135/cropsci1997.0011183X003700030033x

Oury, F. X., Berard, P., Brancourt-Hulmel, M., Depatureaux, C., Doussinault, G., Galic, N., Giraud, A., Heumez, E., Lecomt, C. and Pluchard., P.(2003). Yield and grain protein concentration in bread wheat: a review and a study of multi-annual data from a French breeding program. Journal of Genetics and Breeding. 57, 59-68

Passioura, J. B.(1983). Root and drought resistance. Agricultural Water Management, 7, 265-280.

Pound, M. P., French, A. P., Atkinson, J., Wells, D. M., Bennett, M. J. and Pridmore, T.(2013). RootNav: Navigating images of root architecture. Plant Physiology. 162, 1802-1814.DOI: https://doi.org/10.1104/pp.113.221531

Smith, S. and De Smet, I.(2012). Root system architecture: insights from Arabidopsis and cereal crops. Philosophical Transactions of the Royal Society of London. Series B, Biological Sciences. 367, 1441-1452. https://doi.org/10.1098/rstb.2011.0234

Sparkes, D. L.(2010). Are 'ancient wheat species' more adapted to hostile environments than modern bread wheat? South African Journal of Plant and Soil. 27(4), 331-333. https://doi.org/10.1080 /02571862.2010.10640003

Trethowan, R. M. and Mujeeb-Kazi, A.(2008). Novel germplasm resources for improving environmental stress tolerance of hexaploid wheat. Crop Science. 48, 1255-1265. https://doi. org/10.2135/cropsci2007.08.0477

Vitousek, P. M., Naylor, R. and Crews, T.(2009). Nutrient imbalances in agricultural development. Science. 324, 1519-1520.DOI: 10.1126/science.1170261

Waines, J. and Ehdaie, B.(2007). Domestication and crop physiology: roots of green-revolution wheat. Annals of Botany. 100, 991-998. https://doi.org/10.1093/aob/mcm180

Wojciechowski, T., Gooding, M. J., Ramsay, L. and Gregory, P.J.(2009). The effects of dwarfing genes on seedling root growth of wheat. Journal of Experimental Botany. 60, 2565-2573. https://doi. org/10.1093/jxb/erp107

Xie, Q., Fernando, K.M.C., Mayes, S. and Sparkes, D. L. (2017). Identifying seedling root architectural traits associated with yield and yield components in wheat. Annals of Botany. 119 (7), 11151129. https://doi.org/10.1093/aob/mcx001 